\title{
PERLINDUNGAN HUKUM TERHADAP KONSUMEN PEMBELIAN RUMAH MELALUI PERJANJIAN PENGIKATAN JUAL BELI
}

\author{
LEGAL PROTECTION OF HOME BUYER CONSUMER \\ THROUGH SALES AND PURCHASE AGREEMENT
}

\author{
T. Fauzansyah \\ Mahasiswa Magister Ilmu Hukum, \\ Fakultas Hukum Universitas Syiah Kuala Banda Aceh Indonesia \\ email : ojan.teuku@gmail.com
}

\section{Azhari Yahya}

Dosen Fakultas Hukum Universitas Syiah Kuala Banda Aceh Indonesia Email: azhari.yahya@unsyiah.ac.id

\section{Iman Jauhari}

Dosen Fakultas Hukum Universitas Syiah Kuala Banda Aceh Indonesia Email: imanjauhari@unsyiah.ac.id

\begin{abstract}
This research aims to analyze the position of the PPJB, the legal strength of the PPJB made by the parties, as well as legal protection for consumers of home purchases through the PPJB in the Decision of the Simalungun No. District Court. 35 / PDT.PLW / 2013 / PN-SIM. The method used in the research is juridical-normative research, namely legal research based on secondary data. The results of the study indicate that the Sale and Purchase Agreement (PPJB) made by the parties (Ngadiman and PT Surya Cemerlang) has been carried out in accordance with the provisions of the legislation. Raden Maruhum Hutabarat as the landowner entered into an agreement with PT. Surya Cemerlang as a developer / marketer who entered into a cooperation agreement to build a number of houses which will then be sold to consumers, while the land owner gets a sum of money for the sale of the house. PPJB made by the parties becomes invalid at the time of the Court Decision which decides the legal relationship between the land owner and the developer which is the legality of the land that is traded to the consumer. PPJB made by Ngadiman (Buyer) with PT. Surya Cemerlang has legal powers binding on them and can be used as legal evidence in court. The panel of judges in the Decision of the Simalungun District Court No. 35 / PDT.PLW / 2013 / PN-SIM has not provided justice to Ngadiman as a consumer by not making the principle of consumer protection in accordance with Law Number 8 of 1999 concerning Consumer Protection and the buyer's good faith as legal considerations.
\end{abstract}

Keywords: Legal Protection, Consumer, Purchase Contract.

\begin{abstract}
Abstrak
Penelitian ini bertujuan untuk menganalisa kedudukan PPJB, kekuatan hukum PPJB yang dibuat oleh para pihak, dan perlindungan hukum terhadap konsumen pembelian rumah melalui PPJB dalam Putusan Pengadilan Negeri Simalungun No. 35/PDT.PLW/2013/PN-SIM. Metode yang digunakan dalam penelitian merupakan penelitian yuridis-normatif, yaitu penelitian hukum yang didasarkan pada data sekunder. Hasil penelitian menunjukkan bahwa Perjanjian Pengikatan Jual Beli
\end{abstract}


(PPJB) yang dibuat oleh para pihak (Ngadiman dan PT Surya Cemerlang) telah dilakukan sesuai dengan ketentuan peraturan perundang-undangan. Raden Maruhum Hutabarat selaku pemilik tanah melakukan perjanjian dengan PT. Surya Cemerlang selaku developer/ pemasar yang melakukan perjanjian kerjasama untuk membangun sejumlah rumah yang kemudian akan dijual kepada konsumen, sedangkan pemilik tanah mendapatkan sejumlah uang atas penjualan rumah tersebut. PPJB yang dibuat oleh para pihak menjadi tidak sah pada saat Putusan Pengadilan yang memutus hubungan hukum antara pemilik tanah dengan developer yang merupakan legalitas atas tanah yang diperjualbelikan kepada konsumen. PPJB yang dibuat oleh Ngadiman (Pembeli) dengan PT. Surya Cemerlang memiliki kekuatan hukum mengikat bagi mereka dan dapat digunakan sebagai alat bukti yang sah dipersidangan. Majelis hakim dalam Putusan Pengadilan Negeri Simalungun No. 35/PDT. PLW/2013/PN-SIM belum memberikan keadilan kepada Ngadiman selaku konsumen dengan tidak menjadikan asas perlindungan konsumen sesuai UU Nomor 8 Tahun 1999 Tentang Perlindungan Konsumen dan itikad baik pembeli sebagai pertimbangan hukum.

\section{Kata kunci: Perlindungan, Konsumen, Perjanjian Pengikatan Jual Beli.}

\section{PENDAHULUAN}

Melihat pada Ketentuan UU No 1 Tahun 2011 Tentang Perumahan dan Permukiman Pasal 42 ayat (1), rumah dalam tahap atau proses pembangunan dapat dipasarkan melalui mekanisme perjanjian pendahuluan jual beli sebagaimana ditentukan dalam Peraturan Perundang-Undangan. Ketentuan tersebut sejalan dengan Keputusan Menteri Perumahan Rakyat No.9 Tahun 1995 tentang Pedoman Pengikatan Jual Beli Rumah (PPJB), yang menyebutkan bahwa diperlukan Pedoman Perjanjian Pengikatan Jual Beli Rumah guna memberikan rasa aman serta baik kepada pembeli dan penjual rumah, sehingga nantinya kepentingan konsumen dan penjual akan terjamin. ${ }^{1}$

PPJB diperlukan sebagai upaya untuk mengadakan hubungan hukum antara pembeli dan penjual. Perbuatan hukum yang berkenaan dengan pemilikan rumah salah satunya adalah perbuatan jual beli. ${ }^{2}$ Sebagaimana disebutkan dalam KUHPerdata Pasal 1457, jual beli diartikan sebagai suatu kesepakatan dimana salah satu pihak mengikatkan dirinya untuk menyerahkan suatu benda dan pihak yang lainnya untuk membayarkan harga yang disepakati. Perjanjian Pengikatan Jual Beli tersebut sah apabila memenuhi kriteria yang diatur dalam Pasal 1320 ayat (1) Kitab Undang-Undang Hukum Perdata.

Dalam pelaksanaannya,jual beli yang diawali dengan perjanjian pendahuluan seperti PPJB sering melanggar hak-hak konsumen dan tidak dilaksanakan sesuai dengan peraturan perundang-undangan khususnya Undang-Undang Nomor 8 Tahun 1999 tentang Perlindungan Konsumen (UUPK). ${ }^{3}$

Sebagaimana perkara perdata yang terjadi pada tahun 2013, antara Ngadiman (penggugat) melawan Alm. Raden Maruhum Hutabarat (tergugat 1) dan Michael Sumanto Wijaya (tergugat 2). Ngadiman merupakan salah satu dari sekian banyak orang yang membeli rumah di Perumahan Griya Siantar pada tahun 2004. Raden Maruhum Hutabarat adalah seorang pemilik tanah sekaligus pihak yang turut serta dalam pembangunan perumahan Griya Siantar bekerja sama dengan seorang developer yang bernama Michael Sumanto Wijaya (pimpinan PT Surya Cemerlang) yang bertanggung jawab atas promosi dan penjualan.

\footnotetext{
${ }^{1}$ Nita Dyah Ayuningtyas, “ Akibat Hukum terhadap Pembatalan Akta Pengikatan Jual Beli tanah", Naskah Publikasi Universitas Muhammadiyah Surakarta, Journal Vol. 2 No.5, Juli 2015, hlm. 3

${ }^{2}$ Shinta Christie, Aspek Hukum Perjanjian Pengikatan Jual Beli Sebagai Tahapan Jual Beli Hak Atas Tanah Secara Angsuran, Universitas Indonesia, Jakarta, 2012, hlm.5

${ }^{3}$ Novalia Arnita Simamora, Itikad Baik dalam Perjanjian Pendahuluan (Voor Overeenkomst) Pada Perjanjian Pengikatan Jual Beli Rumah", USU Law Journal, Vol.3. No.3, November 2015. Hlm. 91
} 
Pada tahun 2007 terjadi kemacetan dalam proses pembangunan rumah, pihak pengembang juga sulit ditemui oleh Ngadiman juga pembeli lainnya. Kemacetan pembangunan perumahan tersebut sebagai konsekuensi terjadinya permasalahan hukum antara ahli waris pemilik tanah (Raden Maruhum Hutabarat) dengan developer.

Bahwa terhadap kasus wanprestasi tersebut telah diputus melalui Putusan Pengadilan Negeri Simalungun yang telah dilakukan upaya banding dan kasasi, sebagaimana putusan pengadilan Nomor 355/PDT/2008/PT-MDN, dan Putusan Majelis Hakim Mahkamah Agung RI Nomor 692K/PDT/2010, yang amarnya menolak permohonan kasasi dari terlawan.

Gugatan wanprestasi yang ditujukan kepada Sumanto Michael Wijaya (PT. Surya Cemerlang) sama sekali tidak diketahui oleh para pembeli rumah ataupun ruko perumahan Griya Siantar yang telah melaksanakan PPJB dan melakukan pembayaran DP beserta cicilan kepada PT. Surya Cemerlang. Melihat perbuatan hukum yang dilakukan oleh pembeli, ia telah melaksanakan prestasinya sebagai seorang pembeli yaitu melakukan pembayaran sesuai dengan yang telah disepakati dalam PPJB, oleh karena itu Ngadiman selaku pembeli memiliki itikad baik yang seharusnya dilindungi oleh hukum.

Pada tahun 2012, Victor N selaku kuasa hukum dari ahli waris pemilik tanah melalui berita harian (media cetak) melakukan pengumuman (aanmaning) yang menyatakan terhadap tanah dan bangunan pada Perumahan Griya Siantar akan dilakukan eksekusi, aanmaning tersebut sesuai dengan Putusan Pengadilan Negeri Simalungun No 24/ Pdt/G/2007/PN-SIM jo Putusan Pengadilan Tinggi Medan No 335/Pdt/2008/PT-MDN jo Putusan Mahkamah Agung No $692 \mathrm{~K} / \mathrm{Pdt} / 2011$ yang mengabulkan gugatan pemilik tanah dalam perkara antara pemilik tanah dan developer.

Berdasarkan adanya aanmaning yang ditujukan kepada seluruh pembeli tanah dan bangunan Griya Siantar, maka Ngadiman sebagai salah satu pembeli yang juga punya andil di tanah tersebut merasa perlu untuk mengajukan perlawanan yang diajukan ke Pengadilan Simalungun melalui register perkara nomor No. 35/PDT.PLW/2013/PNSIM.

Majelis hakim Pengadilan Negeri Simalungun dalam putusannya menolak perlawanan Ngadiman dengan beberapa legal reasoning yang dikemukakan oleh hakim. Salah satu pertimbangan hakim adalah bahwa dasar dilakukan eksekusi tersebut sesuai dengan Putusan Pengadilan Negeri Simalungun No 24/Pdt/G/2007/PN-SIM jo Putusan Pengadilan Tinggi Medan No 335/Pdt/2008/PT-MDN jo Putusan Mahkamah Agung No $692 \mathrm{~K} / \mathrm{Pdt} / 2011$ yang mengabulkan gugatan pemilik tanah dalam perkara wanprestasi yang dilakukan developer (pengembang) sehingga pemilik tanah tidak dapat dirugikan.

Akan tetapi, dalam kasus ini terjadi penyimpangan yaitu tidak melihat hak pembeli selaku konsumen yang dilindungi oleh hukum, dan seharusnya majelis hakim juga melihat kepentingan pembeli yang telah melakukan itikad baik disertai dengan pembayaran down payment (DP) serta diikuti dengan Perjanjian Pengikatan Jual Beli (PPJB). ${ }^{4}$ Akibat dari putusan hakim tersebut menimbulkan kerugian materil dan immateril bagi para pembeli yang telah mengeluarkan sejumlah uang untuk membeli tanah dan bangunan yang sekarang menjadi objek sengketa.

Berdasarkan latar belakang yang telah disampaikan di atas, maka dianggap perlu melakukan penelitian lebih lanjut dengan rumusan terkait beberapa hal yaitu, (1). Bagaimanakah kedudukan perjanjian pendahuluan (PPJB) dalam Hukum Perjanjian?

${ }^{4}$ Ridwan Khairandy, Itikad Baik Dalam Kebebasan Berkontrak, Program Pasca Sarjana Fakultas Hukum Universitas Indonesia, Jakarta, 2004, hlm. 13

274 IUS Kajian Hukum dan Keadilan 
(2) Bagaimanakah kekuatan hukum Perjanjian pendahuluan (PPJB) yang dibuat oleh penjual dan pembeli? Dan (3) Bagaimanakah perlindungan hukum terhadap pembeli rumah dalam Putusan PN Simalungun No. 35/PDT.PLW/2013/PN-SIM dilihat dari perspektif UU Nomor 8 tahun 1999 tentang Perlindungan Konsumen?

Adapun yang menjadi tujuan dari penelitian ini adalah untuk mendapatkan gambaran mendalam terhadap persoalan yang telah dikemukakan dalam rumusan masalah. Untuk mengkaji dan menganalisis kedudukan Perjanjian Pengikatan Jual Beli (PPJB) dalam Hukum Perjanjian, untuk mengkaji dan menganalisis kekuatan hukum Perjanjian Pengikatan Jual Beli (PPJB) Tanah dan Bangunan 092/Psc Mdn/ PPJB/Gs/X/2004 yang dibuat oleh Pengembang (developer) dan pembeli, serta untuk mengetahui dan menjelaskan perlindungan hukum terhadap pembeli dalam Pengadilan Negeri Simalungun No. 35/PDT.PLW/2013/PN-SIM.

Metode penelitian yang digunakan dalam penyusunan tulisan ini merupakan penelitian normatif, yaitu penelitian yang menitikberatkan pada studi dokumen atau bahan pustaka serta peraturan perundangan. Sumber data yang digunakan dalam penelitian ini adalah data sekunder, yaitu bahan hukum primer, bahan hukum sekunder dan bahan hukum tersier. Dengan menggunakan metode analisis normatif, dapat menginterpretasikan bahan hasil penelitian berdasarkan norma-norma dan teori hukum.

\section{PEMBAHASAN}

\section{Kedudukan Perjanjian Pengikatan Jual Beli (PPJB) Dalam Hukum Perjanjian}

Kedudukan PPJB merupakan suatu perjanjian yanglahir karena adanya asas kebebasan berkontrak. Kebebasan berkontrak berkaitan erat dengan asas konsensualisme atau sepakat antara para pihak yang membuat perjanjian. Tanpa adanya sepakat dari salah satu pihak yang membuat perjanjian, maka perjanjian yang dibuat adalah tidak sah. Sebaliknya, apabila suatu perjanjian berdasarkan kesepakatan, kecakapan, memenuhi objek tertentu serta klausul yang halal maka perjanjian tersebut sah dan mengikat para pihak. Oleh karena itu, PPJB berkedudukan sebagai salah satu jenis perjanjian yang obligatoir dan konsensuil yang tunduk pada ketentuan Pasal 1320, Pasal 1457, serta Pasal 1338 Kitab Undang-Undang Hukum Perdata. ${ }^{5}$

Perikatan jual beli bertahap merupakan suatu perjanjian yang tidak diatur dalam Undang-Undang, serta sebagai perjanjian permulaan atau pendahuluan untuk proses ke Akta Jual Beli (AJB). ${ }^{6}$

Perjanjian jual beli secara umum tunduk pada hukum perikatan, namun belum mengakibatkan berpindahnya hak atas suatu kebendaan kepada pihak lainnya. Perjanjian pengikatan jual beli belum menyebabkan berpindahnya hak kepemilikan atas suatu benda dari penjual kepada pembeli. PPJB merupakan kesepakatan yang harus diikuti dengan perjanjian penyerahan benda setelah prestasi antara kedua belah pihak dilaksanakan. ${ }^{7}$

Ketentuan sebagaimana tersebut dalam Pasal 1313 KUHPerdata merumuskan bahwasanya perjanjian adalah suatu perbuatan dimana satu orang ataulebih mengikatkan

\footnotetext{
${ }^{5}$ R.Subekti, R Tjitrosudibio, Kitab Undang-undang Hukum Perdata, Undang-Undang Agraria dan Undang-Undang Perkawinan, PT. Pradnya Paramita, Jakarta, 2001, hlm. 128

${ }^{6}$ Yudi Setia Permana, Tanggung Jawab Notaris Dalam Penyimpanan Sertifikat Hak Atas Tanah Pada Perikatan Jual Beli Bertahap, Jurnal IUS Vol V Nomor 3, Desember 2017, Hal 448- 462

${ }^{7}$ Yusuf Sofie, 2008, Perlindungan Konsumen dan Instrumen-Instrumen Hukumnya, PT. Citra Aditya Bakti Bandung, hlm. 83-84. Lihat juga Abdul hakim, Op.Cit., hlm. 120
} 
diri terhadap satu orang lain atau lebih. ${ }^{8}$ Definisi tersebut tidak hanya mengkaji kontrak pada tahap kontraktual, tetapi juga memperhatikan perbuatan sebelum dan sesudahnya. Perbuatan sebelumnya (pra-contractual) meliputi tahap penawaran dan penerimaan, sedangkan perbuatan sesudahnya (post-contractual) adalah pelaksanaan perjanjian. ${ }^{9}$

Suatu perjanjian haruslah memenuhi syarat sebagaimana disebutkan dalam Pasal 1320 ayat (1) KUHPerdata yaitu suatu perjanjian itu sah apabila memenuhi 4 syarat, yaitu: tercapai kata sepakat; Cakap untuk membuat perjanjian; terdapat suatu hal tertentu; Adanya causa yang halal. Syarat pertama dan kedua merupakan syarat subjektif yang apabila tidak terpenuhi maka perjanjian tersebut dapat dibatalkan sedangkan syarat ketiga dan keempat merupakan syarat objektif yang jika tidak dipenuhi maka perjanjian tersebut adalah batal demi hukum. ${ }^{10}$

Melihat asas kebebasan berkontrak yang ditentukan oleh Undang-undang, para pihak dapat dengan bebas mengatur isi perjanjian sesuai dengan apa yang mereka butuhkan, namun dengan tidak terlepas dengan batasan yang telah ditentukan dan juga perjanjian tersebut haruslah dilaksanakan dengan itikad baik. ${ }^{11}$ Pasal 1338 ayat (1) Kitab Undangundang Hukum Perdata menyatakan bahwa persetujuan yang dibuat oleh para pihak secara sah berlaku sebagai undang-undang bagi para pihak dan/atau mereka yang membuat perjanjian tersebut.

PPJB yang dibuat oleh developer dan pembeli membuktikan bahwa adanya hubungan antara developer dengan pembeli secara hukum. Perbuatan hukum yang akan ada selanjutnya adalah perjanjian jual beli yang diikuti pembuatan Akta Jual Beli di mana akan terjadi perlaihan hak atas tanah dan bangunan dari developer kepada pembeli yang ditandatangani dan dibuat hadapan Pejabat Pembuat Akta Tanah (PPAT). ${ }^{12}$

Ngadiman (perorangan) dan PT. Surya Cemerlang (Badan Hukum) merupakan subjek hukum yang cakap untuk melakukan perbuatan hukum jual beli. Baik Ngadiman maupun PT. Surya Cemerlang bukanlah subjek hukum yang berada di bawah pengampuan dan juga bukanlah merupakan seorang yang telah dinyatakan pailit, sehingga Ngadiman dan PT. Surya Cemerlang merupakan subjek hukum yang telah memenuhi syarat cakap untuk mengadakan perikatan sebagaimana ditentukan oleh Pasal 1320 KUHPerdata. ${ }^{13}$

Kedudukan PPJB merupakan suatu perjanjian yang lahir karena adanya asas kebebasan berkontrak. Kebebasan berkontrak berkaitan erat dengan asas konsensualisme atau sepakat antara para pihak yang membuat perjanjian. Tanpa adanya sepakat dari salah satu pihak yang membuat perjanjian, maka perjanjian yang dibuat adalah tidak sah. Sebaliknya, apabila suatu perjanjian berdasarkan kesepakatan, kecakapan, memenuhi objek tertentu serta klausul yang halal maka perjanjian tersebut sah dan mengikat para pihak. Oleh karena itu, PPJB berkedudukan sebagai salah satu jenis perjanjian yang obligatoir dan konsensuil yang tunduk pada ketentuan Pasal 1320, Pasal 1457, serta Pasal 1338 Kitab Undang-Undang Hukum Perdata. ${ }^{14}$

Klausul yang disusun dalam PPJB merupakan Klausula baku yang dibuat oleh developer dan disepakati isinya oleh pembeli, sesuai dengan Pasal 1338 KUHPerdata

\footnotetext{
${ }^{8}$ Salim HS, Hukum Kontrak Teori dan Teknik Penyusunan Kontrak, Sinar Grafika, Jakarta, 2010, hlm.4

${ }^{9}$ Mariam Darus Badrulzaman, dkk, Kompilasi Hukum Perikatan, PT. Citra Aditya Bakti, Bandung, 2001, hlm.66

${ }^{10}$ Herlien Budiono, Ajaran Umum Hukum Perjanjian dan Penerapannya di Bidang Kenotariatan, Citra Aditya Bakti, Bandung, 2009, hlm. 5

${ }^{11}$ Munir Fuadi, Hukum Kontrak (Dari Sudut Pandang Hukum Bisnis), PT. Citra Aditya Bakti, Bandung, 2001, hlm. 72

${ }^{12}$ Ibid

${ }^{13}$ Antari Innaka, Penerapan Asas Itikad Baik Tahap Prakontraktual Pada Perjanjian Jual Beli Perumahan, Jurnal Mimbar Hukum, No.3. Vol.24., Oktober 2012.

${ }^{14}$ Soebekti, Bunga Rampai Ilmu Hukum, Alumni, Bandung, 1992, hlm. 4
} 
yaitu asas kebebasan berkontrak, maka perjanjian tersebut berlaku sebagai undangundang bagi mereka yang harus dipenuhi satu sama lainnya dan haruslah dilaksanakan dengan itikad baik. ${ }^{15}$

\section{Kekuatan Hukum Perjanjian Pengikatan Jual Beli (PPJB)}

Perjanjian antara Raden Maruhum Hutabarat (Pemilik Tanah) dan PT. Surya Cemerlang (Developer) yang dibuat secara sah dan mengikat para pihak, di mana Raden Maruhum Hutabarat selaku pemilik tanah melakukan perjanjian dengan PT. Surya Cemerlang selaku (developer)/pemasar melakukan perjanjian kerjasama untuk membangun sejumlah rumah yang kemudian akan dijual kepada konsumen, di mana pemilik tanah akan mendapatkan sejumlah uang atas penjualan rumah tersebut. Namun atas wanprestasi yang dilakukan PT. Surya Cemerlang berakibat kepada konsumen, yaitu hilangnya hak atas tanah dan bangunan yang menjadi objek PPJB yang dibuat oleh para pihak, karena legalitas atas tanah tersebut yang diperoleh atas dasar perjanjian telah dibatalkan oleh pengadilan. PPJB yang dibuat oleh Ngadiman (Pembeli) dengan PT. Surya Cemerlang memiliki kekuatan hukum mengikat bagi mereka dan dapat digunakan sebagai alat bukti yang sah di persidangan.

Asas itikad baik dan juga asas kebebasan berkontrak dalam pelaksanaan perjanjian pertama kali diperkenalkan oleh KUHPerdata, sebagaimana terdapat dalam Pasal 1320 ayat (1) dan 1338 ayat (3) KUHPerdata. ${ }^{16}$ Undang-Undang Perlindungan Konsumen mewajibkan setiap pelaku usaha untuk beritikad baik dalam melakukan kegiatan usahanya dan juga memperlakukan konsumen secara jujur dan benar, tidak diskriminatif dan yang terpenting adalah pelaku usaha bertanggungjawab terhadap apa yang ia usahakan, salah satunya adalah memberikan bentuk ganti rugi kepada konsumen atas penjualan yang tidak sesuai dengan apa yang dijanjikan. Dalam hal sengketa telah masuk wilayah pengadilan, perlindungan konsumen haruslah menjadi dasar hakim dalam memutuskan suatu perkara.

Bentuk itikad baik objektif yang dilakukan Ngadiman adalah dengan melaksanakan isi perjanjian yang tertuang dalam PPJB yaitu Booking Fee Receive atas nama Ngadiman tanggal 29 September 2004 yang diterima oleh PT. Putra Surya Cemerlang. Ngadiman telah membayar uang sebesar Rp.82.619.705 kepada PT. Putra Surya Cemerlang yang terdiri dari booking fee sebesar Rp.3.500.000.- Down Payment sebesar Rp.26.500.000.dan sisa pembayaran sebesar Rp.52.619.705 yang dicicil selama 18 bulan atas pembelian tanah seluas $96 \mathrm{~m} 2$ dan bangunan rumah tempat tinggal yang terletak di Proyek Griya Siantar kavling 69 D Blok type Dahlia Standar.

Ruang lingkup itikad baik yang diatur dalam Kitab Undang-Undang Hukum Perdata di beberapa negara seperti di Indonesia masih diletakkan pada pelaksanaan kontrak saja. Hal itu terlihat dari bunyi pasal 1338 ayat (3) Kitab Undang-undang Hukum Perdata Indonesia yang menyatakan bahwa "suatu perjanjian harus dilaksanakan dengan itikad baik".

PPJB yang dibuat oleh Ngadiman dan PT. Surya Cemerlang telah memenuhi syarat sahnya perjanjian sebagaimana Pasal 1320 KUHPerdata dan memiliki kekuatan mengikat bagi mereka yang membuatnya. Oleh karena klausul yang disusun dalam PPJB merupakan Klausula baku yang dibuat oleh developer dan disepakati isinya oleh pembeli, sesuai dengan pasal 1338 KUHPerdata yaitu asas kebebasan berkontrak, maka

\footnotetext{
${ }^{15}$ Herlien Budiono, Ajaran Umum Hukum Perjanjian dan Penerapannya di Bidang Kenotariatan, Citra Aditya Bakti, Bandung, 2009, hlm. 5

${ }^{16}$ Antari Innaka, Penerapan Asas Itikad Baik Tahap Prakontraktual Pada Perjanjian Jual Beli Perumahan, Jurnal Mimbar Hukum, No.3. Vol.24., Oktober 2012. Hlm. 377
} 
perjanjian tersebut berlaku sebagai undang-undang bagi mereka yang harus dipenuhi satu sama lainnya. ${ }^{17}$ Pencantuman klasula baku di dalam perjanjian baku pada dasarnya tidak menempatkan kedudukan konsumen setara dengan pelaku usaha, berdasarkan prinsip kebebasan berkontrak dan rentan terjadinya penyalahgunaan keadaan oleh pihak yang memiliki kedudukan lebih kuat dalam kontrak. ${ }^{18}$

Daya pembuktian formil titik permasalahannya menyangkut kebenaran identitas tanda tangan dan penandatanganan. ${ }^{19}$ Orang yang bertandatangan dianggap benar menerangkan hal yang tercantum dalam akta. Berdasarkan kekuatan formil ini, hukum mengakui, siapa saja atau orang yang menandatangani akta di bawah tangan: (1) dianggap benar menerangkan seperti apa yang dijelaskan dalam akta; (2) berdasar kekuatan formil yang demikian, meski dianggap terbukti tentang adanya pernyataan dari penanda tangan: surat keterangan yang saya tanda tangani benar berisi keterangan saya; (3) dengan demikian daya kekuatan pembuktian akta di bawah tangan tersebut meliputi: (a) kebenaran identitas penandatangan; (b) menyangkut kebenaran identitas orang yang memberi.

Daya pembuktian materiil, fokus pada permasalahannya berkenaan dengan kebenaran isi keterangan yang tercantum di dalam akta di bawah tangan. Benar atau tidak isinya dan sejauh mana kebenaran isinya yang tercantum di dalamnya, prinsip yang harus ditegakkan menghadapi penerapan daya pembuktian materiil adalah: (1) secara materiil isi keterangan yang tercantum di dalam akta di bawah tangan, harus dianggap benar; (2) dalam arti, apa yang diterangkan dalam akta oleh penandatangan, dianggap benar sebagai keterangan yang dikehendakinya; (3) dengan demikian secara materiil, isi yang tercantum dalam akta di bawah tangan mengikat kepada diri penandatangan. ${ }^{20}$

Jika dikaitkan dengan PPJB yang dibuat oleh PT Surya Cemerlang yang kemudian disepakati Ngadiman di hadapan Notaris PPAT (Waarmerking) maka PPJB tersebut memiliki kekuatan pembuktian formil. Hal tersebut senada dengan ketentuan Pasal 1875 KUHPerdata, yaitu ketika para pihak mengakui kebenaran dari tanda tangan dalam PPJB tersebut maka PPJB dapat menjadi alat bukti yang sempurna bagi para pihak. Dengan diakui dan tidak disangkalnya tanda tangan dalam akta di bawah tangan maka kekuatan pembuktian formal dari akta di bawah tangan itu sama dengan kekuatan pembuktian formal akta otentik. ${ }^{21}$

\section{Perlindungan Hukum Terhadap Pembeli Rumah Dalam Putusan PN Simalungun No. 35/PDT.PLW/2013/PN-SIM}

Putusan PN Simalungun Nomor 35/PDT.PLW/2013/PN-SIM dianggap kurang memberikan perlindungan hukum kepada Ngadiman (pembeli), karena putusan tersebut mengakibatkan Ngadiman mengalami kerugian materil. Seharusnya hakim dapat melihat itikad baik objektif dari Ngadiman yaitu berupa pelaksanaan kewajiban sebagaimana tertuang dalam perjanjian sebagaimana tertuang dalam Yurisprudensi Mahkamah Agung No 120K/SIP/1957. Dalam putusannya, majelis hakim mengedepankan kepastian hukum yang terkandung dalam bukti kepemilikan tanah

\footnotetext{
${ }^{17}$ Nurjannah, "Penerapan Klausul Eksonerasi dan Akibat Hukumnya dalam Perjanjian Pembiayaan Musyarakah Pada Bank Syariah (Studi Putusan Pengadilan Agama Nomor 967/Pdt.G/2012/PA.Mdn)", USU Law Journal, Vol.4. No.1, Februari 2016.

${ }^{18}$ Pasal 24 UUPK

${ }^{19}$ Ramli Usman, Ilyas Ismail, Azhari, "Kekuatan Pembuktian Sertifikat Dalam Sengketa Hak Atas Tanah", Jurnal Ilmu Hukum Pascasarjana Universitas Syiah Kuala, Vol.4. No.3, Agustus 2016

${ }^{20}$ M.Yahya Harahap, Hukum Acara Perdata tentang Gugatan, Persidangan, Penyitaan, Pembuktian, dan Putusan Pengadilan, Sinar Grafika, Jakarta, 2005, hal.820

${ }^{21}$ M. Yahya Harahap, Op. Cit., hlm 591.
} 
dan bangunan daripada melakukan rechtsvinding salah satunya adalah mengukur itikad baik serta kerugian materil yang dialami oleh Ngadiman sebagai konsumen.

Majelis hakim dalam Putusan Pengadilan Negeri Simalungun No. 35/PDT.PLW/2013/ PN-SIM belum memberikan keadilan kepada Ngadiman selaku konsumen dengan tidak menjadikan asas-asas perlindungan konsumen sesuai Undang-Undang Nomor 8 Tahun 1999 tentang Perlindungan Konsumen dan itikad Baik pembeli sebagai pertimbangan hukum (legal reasoning).

Putusan Pengadilan Negeri Simalungun No. 35/PDT.PLW/2013/PN-SIM hanya melihat kepastian hukum objek sengketa tanpa melakukan analisa rangkaian peristiwa sampai terjadinya sengketa yang menyebabkan kerugian pada Ngadiman. Perlindungan hukum secara preventif melalui norma Pasal 19 UUPK menjamin pemberian ganti rugi kepada pembeli yang mengalami kerugian akibat perbuatan pelaku usaha (pemilik tanah dan developer).

Dalam menyelesaikan perkara melalui proses pengadilan, hakim tidak hanya berfungsi dan berperan memimpin jalannya persidangan, akan tetapi hakim juga berfungsi bahkan berkewajiban mencari dan menemukan hukum objektif atau materil yang akan diterapkan dalam memutus perkara yang disengketakan para pihak. ${ }^{22}$

Hakim dapat menemukan hukum dari sumber-sumber hukum, yaitu undang-undang, kebiasaan, traktat, yurisprudensi, doktrin, bahkan keyakinan hukum yang dianut masyarakat. Penemuan hukum lazimnya diartikan sebagai proses pembentukan hukum oleh atau petugas-petugas hukum lainnya yang diberi tugas melaksanakan hukum terhadap peristiwa-peristiwa hukum yang konkret. Ini merupakan proses konkretisasi dan individualisasi peraturan hukum yang bersifat umum dengan mengingat peristiwa konkret. $^{23}$

Perjanjian pendahuluan yang dibuat PT. Surya Cemerlang dan Ngadiman merupakan suatu perjanjian yang sah dan mengikat masing-masing pihak. Perjanjian tersebut memperlihatkan adanya itikad baik para pihak, dan oleh karenanya hendaknya penegak hukum memberikan perlindungan kepada Ngadiman selaku pembeli yang beritikad baik.

Harusnya hakim menjadikan Undang-Undang Perlindungan Konsumen dan asas itikad baik sebagai dasar putusannya untuk menjamin hak-hak konsumen yang telah dirugikan dalam kasus dalam Putusan Pengadilan Negeri Simalungun No. 35/PDT. PLW/2013/PN-SIM. Sebagaimana tujuan UUPK yaitu memberikan harapan bagi masyarakat Indonesia, untuk memperoleh perlindungan atas kerugian yang diderita atas transaksi suatu barang dan jasa, UUPK menjamin adanya kepastian hukum bagi konsumen dan tentunya perlindungan konsumen tersebut tidak pula merugikan produsen, namun karena kedudukan konsumen yang lemah maka pemerintah berupaya untuk memberikan perlindungan melalui peraturan Perundang-undangan yang berlaku dan pemerintah juga melakukan pengawasan terhadap dilaksanakannya peraturan perundang-undangan tersebut oleh berbagai pihak yang terkait.

\section{SIMPULAN}

Perjanjian Pengikatan Jual Beli yang dibuat oleh para pihak (Ngadiman dan PT. Surya Cemerlang) telah dilakukan sesuai dengan ketentuan peraturan perundang-undangan.

\footnotetext{
${ }^{22}$ M.Yahya Harahap, Hukum Acara Perdata tentang Gugatan, Persidangan, Penyitaan, Pembuktian, dan Putusan Pengadilan, Sinar Grafika, Jakarta, 2005, hal.820.

${ }^{23}$ Sudikno Mertokusumo dan Mr.A.Pitlo, Bab-bab tentang Penemuan Hukum, Citra Aditya Bakti bekerjasama dengan Konsorsium Ilmu Hukum, Departemen Pendidikan dan Kebudayaan dan The Asia Foundation, Yogyakarta, 1993, hal.4.
} 
Dasar perjanjian yang merujuk pada asas kebebasan berkontrak sebagaimana Pasal 1338 (1) KUHPerdata dan dibuat sesuai dengan syarat sahnya perjanjian sebagaimana tertuang dalam Pasal 1320 KUHPerdata sehingga perjanjian tersebut berlaku sebagai undang-undang bagi mereka yang membuatnya. ${ }^{24}$

Perjanjian antara Raden Maruhum Hutabarat (Pemilik Tanah) dan PT. Surya Cemerlang (Developer) yang dibuat secara sah dan mengikat para pihak, di mana Raden Maruhum Hutabarat selaku pemilik tanah melakukan perjanjian dengan PT. Surya Cemerlang selaku developer/pemasar melakukan perjanjian kerjasama untuk membangun sejumlah rumah yang kemudian akan dijual kepada konsumen, di mana pemilik tanah akan mendapatkan sejumlah uang atas penjualan rumah tersebut. Namun atas wanprestasi yang dilakukan PT. Surya Cemerlang berkibat kepada konsumen, yaitu hilangnya hak atas tanah dan bangunan yang menjadi objek PPJB yang dibuat oleh para pihak, karena legalitas atas tanah tersebut yang diperoleh atas dasar perjanjian telah dibatalkan oleh pengadilan. PPJB yang dibuat oleh Ngadiman (Pembeli) dengan PT. Surya Cemerlang memiliki kekuatan hukum mengikat bagi mereka dan dapat digunakan sebagai alat bukti yang sah di persidangan.

Majelis hakim dalam Putusan Pengadilan Negeri Simalungun No. 35/PDT.PLW/2013/ PN-SIM belum memberikan keadilan kepada Ngadiman selaku konsumen dengan tidak menjadikan asas-asas perlindungan konsumen sesuai Undang-Undang Nomor 8 Tahun 1999 Tentang Perlindungan Konsumen dan itikad baik pembeli sebagai pertimbangan hukum (legal reasoning). Serta hakim dalam putusannya juga tidak mencantumkan pertimbangan penolakan.

\section{DAFTAR PUSTAKA}

\section{Buku}

Agus Yudha Hernoko, (2011), Hukum Perjanjian Asas Proporsionalitas dalam Kontrak Komersial, Kencana Prenada Media Group, Jakarta.

Herlien Boediono, (2010), Ajaran Umum Hukum Perjanjian dan Penerapannya di Bidang Kenotariatan, Citra Aditya Bakti, Bandung.

Mariam Darus Badrulzaman, (2009), Kompilasi Hukum Perikatan, Citra Aditya Bakti, Bandung.

Munir Fuadi, (2001), Hukum Kontrak (Dari Sudut Pandang Hukum Bisnis, PT. Citra Aditya Bakti, Bandung

R.Subekti, R Tjitrosudibio, (2001), Kitab Undang-undang Hukum Perdata, UndangUndang Agraria dan Undang-Undang Perkawinan, PT. Pradnya Paramita, Jakarta.

Ridwan Khairandy, (2004), Itikad Baik Dalam Kebebasan Berkontrak, Program Pascasarjana Fakultas Hukum Universitas Indonesia, Jakarta

Shinta Christie, (2012), Aspek Hukum Perjanjian Pengikatan Jual Beli Sebagai Tahapan Jual Beli Hak Atas Tanah Secara Angsuran, Universitas Indonesia, Jakarta.

Sudikno Mertokusumo dan Mr.A.Pitlo, (1993), Bab-bab tentang Penemuan Hukum, Citra Aditya Bakti bekerjasama dengan Konsorsium Ilmu Hukum, Departemen Pendidikan dan Kebudayaan dan The Asia Foundation, Yogyakarta.

${ }^{24}$ Agus Yudha Hernoko, Hukum Perjanjian Asas Proporsionalitas dalam Kontrak Komersial, Kencana Prenada Media Group, Jakarta, 2011, hlm. 141 


\section{Journal}

Antari Innaka, (2012 ), "Penerapan Asas Itikad Baik Tahap Prakontraktual Pada Perjanjian Jual Beli Perumahan", Jurnal Mimbar Hukum, No.3. Vol.24., Oktober. Hlm. 504-514

Luh Nila Winarmi, (2015 ), "Asas Itikad Baik Sebagai Upaya Perlindungan Konsumen dalam Perjanjian Pembiayaan”, Jurnal Ilmu Hukum, No. 21. Vol.11, Februari.

Nita Dyah Ayuningtyas, (2015 ), "Akibat Hukum terhadap Pembatalan Akta Pengikatan Jual Beli tanah", Naskah Publikasi Universitas Muhammadiyah Surakarta, Journal Vol. 2 No.5, Juli.

Novalia Arnita Simamora, (2015), "Itikad Baik dalam Perjanjian Pendahuluan (Voor Overeenkomst) Pada Perjanjian Pengikatan Jual Beli Rumah", USU Law Journal, Vol.3. No.3, November.

Nurjannah, (2016 ), "Penerapan Klausul Eksonerasi dan Akibat Hukumnya dalam Perjanjian Pembiayaan Musyarakah Pada Bank Syariah (Studi Putusan Pengadilan Agama Nomor 967/Pdt.G/2012/PA.Mdn)", USU Law Journal, Vol.4. No.1, Februari.

Ramli Usman, Ilyas Ismail, Azhari, (2016 ), "Kekuatan Pembuktian Sertifikat Dalam Sengketa Hak Atas Tanah", Jurnal Ilmu Hukum Pascasarjana Universitas Syiah Kuala, Vol.4. No.3, Agustus.

Yudi Setia Permana, (2017), Tanggung Jawab Notaris Dalam Penyimpanan Sertifikat Hak Atas Tanah Pada Perikatan Jual Beli Bertahap, Jurnal IUS Vol V Nomor 3, Desember.

\section{Peraturan Perundang-Undangan}

Kitab Undang-Undang Hukum Perdata

Putusan Pengadilan Negeri Simalungun No. 35/PDT.PLW/2013/PN-SIM

Undang-Undang No 1 Tahun 2011 Tentang Perumahan dan Permukiman

Undang-Undang Nomor 48 Tahun 2009 Tentang Kekuasaan Kehakiman

Undang-Undang Nomor 8 Tahun 1999 Tentang Perlindungan Konsumen

Yurisprudensi Putusan Mahkamah Agung RI No 120K/SIP/1957

Yurisprudensi Putusan Mahkamah Agung RI No 251K/Sip/1958

Yurisprudensi Putusan Mahkamah Agung RI No 3201K/Pdt/1991 